\title{
PLANKTON BIOSTRATIGRAPHY AND PALEOCLIMATIC IMPLICATIONS OF AN EARLY LATE MIOCENE SEQUENCE OF LEVKAS ISLAND, IONIAN SEA, GREECE
}

\author{
Antonarakou, A. \\ Department of Historical Geology and Palaeontology, Faculty of Geology and Geoenvironment, \\ University of Athens, Panepistimiopolis 15784,Athens, Greece, aantonar@geol.uoa.gr
}

\begin{abstract}
Planktonic foraminiferal biostratigraphy is carried out in an Early Tortonian tectonically active setting, located in the Pre-Apulian Foreland Basin in Levkas Island. The studied section (Manassi section) is composed of hemipelagic silty clays and turbidite sandstones, reflecting sedimentation as a result of thrust activity. The distributional pattern of biostratigraphical significant species suggests that the Manassi section has been deposited during the time interval that Globigerinoides obliquus occurs regularly, the neogloboquadriniids are present in low percentages and Paragloborotalia siakensis is continuously present. The correlation with astronomical tuned sections allowed dating the studied section as ranging between 11.54Ma to 11.2Ma, having a lower Tortonian age, above the Serravallian/Tortonian boundary (Paragloborotalia siakensis planktonic foraminiferal zone).

On the basis of the obtained palaeoclimatic curve, a series of palaeoclimatic events are recognized. The faunal composition suggests a cooling trend in the lower part which has been correlated with the Mi5 event. This cooling is followed by a warm-temperate phase, punctuated by several negative peaks in the palaeoclimatic curve. The palaeoclimatic evolution of the study area generally corresponds to the global palaeoclimatic trend with some subtle differences, supporting that the regional climate of this area was not merely controlled by global changes in climate.
\end{abstract}

Key words: planktonic foraminifera, early Tortonian, palaeoclimate, Mediterranean.

\section{Introduction}

The Miocene epoch represents a bridge between the warm interval of the Paleogene and the cold Neogene period. There is enough evidence available to suggest that the Miocene was a critical time in the evolution of the Earth's climate marked by a major expansion of Antarctic ice volume, deep-sea cooling, isotopic excursions (Savin et al., 1981; Kennett \& Barker, 1990) and widespread deep-sea hiatuses (Keller \& Barron, 1987). The increased ice volume on Antarctica during the Miocene steepened the latitudinal thermal gradients and caused sea-level fluctuations. Late Oligocene-middle Miocene physico-chemical conditions of the deep ocean were considerably different from those of today, while the late Miocene deep ocean was in several ways similar to the present day.

The period from Middle to early Late Miocene (15-11 Ma) is regarded as a major period of expansion of the Antarctic ice and a deep-water benthic faunal turnover (e.g., Miller et al., 1991; Kaiho, 1994). This period is thus a period of major interest in Cenozoic climate development. High-reso- 
lution oxygen isotope records have been used to reconstruct the history of the Antarctic ice sheet (e.g. Miller et al., 1987; Woodruff \& Savin, 1991; Miller et al., 1991b; Flower \& Kennett, 1993; Flower $\&$ Kennett, 1995) and have revealed a step-like pattern of ice-volume expansion during that period. Miller et al., 1991 summarized the oxygen isotope stratigraphy for this time interval and indicated four $\delta^{18} \mathrm{O}$ maxima labelled Mi3, Mi4, Mi5 and Mi6 events respectively, which have been regarded as evidence of ice-growth events. The Mi3 and Mi4 maxima correspond to the early and middle phases of middle Miocene climatic cooling and/or Antarctic ice-sheet expansion (Shackleton \& Kennett, 1975; Savin et al., 1975; Woodruff et al., 1981), whereas Mi5 has been interpreted to be the first significant ice sheet.

The early Tortonian is characterized by a stable climate system, based on previous stable isotope analyses from ocean drilling cores and stratigraphic studies (Turco et al., 2001; Miller et al. 1991; Zachos et al., 2001; Ohta et al., 2003; Holbourn et al., 2004). Understanding the early Late Miocene climate is integral to the study of global climate interactions. Sedimentary sequences from the Mediterranean basin are commonly used for studying Cenozoic climate variability as their marine sedimentary outcrops reflect climate changes in the rock record through alternating, rhythmic colour and lithological variations.

The present study refers to the early Late Miocene (early Tortonian) palaeoclimatic evolution of eastern Mediterranean and more precisely, of the Ionian Sea (Levkas island, Manassi section). The results are based on the analysis of the high-resolution planktonic foraminiferal record from this section. The data of calcareous plankton are compared with $\delta^{18} \mathrm{O}$ variations for Gibliscemi section described by Turco et al. (2001), and for ODP Site 926 described by Turco et al. (2002). This analysis enables us to examine the interactions among the variables (foraminiferal species) and identify a series of palaeoclimatic events of long and short duration that took place in the Mediterranean area during the early Tortonian. Our main objectives are to provide a detailed time-stratigraphic correlation on the basis of planktonic foraminiferal studies that aim to unravel the evolution of sedimentary basin and the influence of past climatic changes on sedimentary properties and faunal distribution pattern on a regional as well as on a global scale.

\section{Materials and methods}

\subsection{Geological setting and lithology of the studied section}

The studied section is located in one of the most tectonically active regions of the Eastern Mediterranean, the Ionian Islands in western Greece (Fig. 1).

The Ionian Islands constitute part of the para-autochthonous Apulian foreland of the Hellenide orogen and include rocks of the Pre-Apulian (or Paxos) and Ionian isopic zones (Aubouin 1965; Underhill 1989) (Fig. 1). The Pre-Apulian or Paxos zone corresponds to neritic sedimentation, reaching into the Aquitanian, overlain by Miocene marl sequence, represented on Paxos Island, western Levkas and parts of the islands of Cephalonia and Zakynthos (IGRS-IFP, 1966). More specifically, in Levkas Island, the Pre-Apulian zone is represented in Agios Petros area which covers the southwestern part of the island (Fig. 2).

In the northern part of Agios Petros area, the Manassi section may be considered an early Late Miocene representative sequence of the Pre-Apulian zone (Fig. 2). During Early Tortonian a fundamental change in the palaeogeographic configuration of the Pre-Apulian zone took place: the preexisting shallow platform, on which bioclastic calcareous sedimentation took place, rapidly subsided and marls and clays were deposited until the Pliocene (Bornovas, 1964; de Mulder, 1975). 

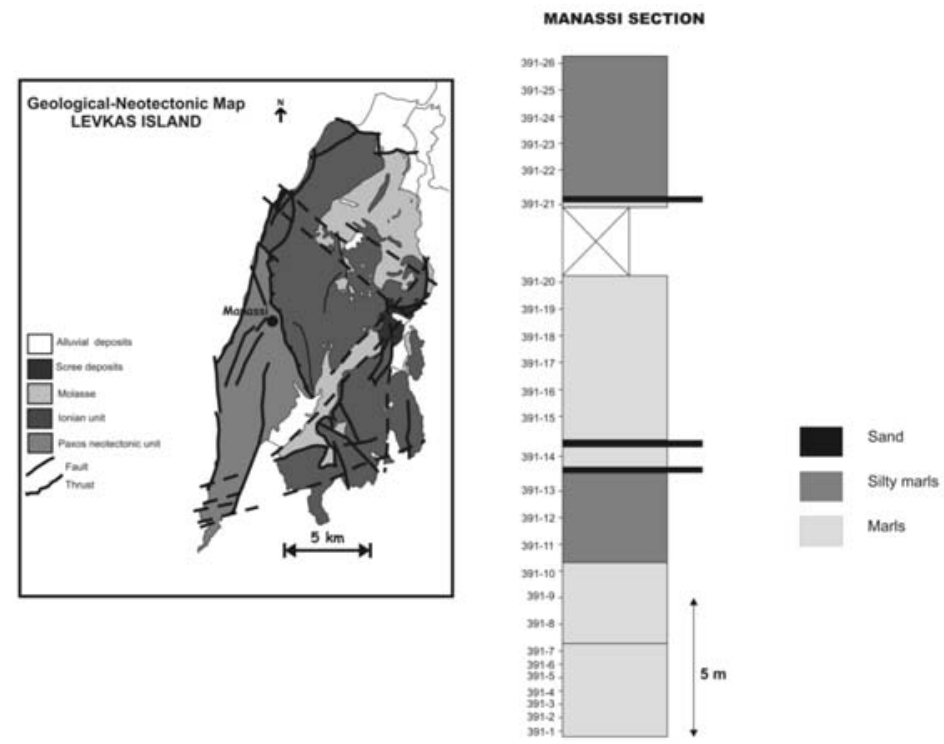

Fig. 1: Geological and Neotectonic map of Levkas Island (after Lekkas et al., 2001, modified), depicting the location of the studied area. Lithology and position of samples of Manassi section

The Manassi section is located on the eastern slope of a N-S running valley, near the homonym village. The studied succession consists of blue grey marls and clays with some fine grained sandstone interbeds. The intercalations of these thin, clastic beds and especially of positively graded sandstones in the studied succession reflect the influence of density currents, which supplied coarser material from a distant hinterland (de Mulder, 1975).

\subsection{Planktonic foraminifera}

The Manassi section ( $25 \mathrm{~m}$ thick) was sampled with 0.5 to $1 \mathrm{~m}$ resolution. A total of 26 samples were collected. A preliminary bulk rock composition analysis indicated that the stratigraphic interval from $19.9 \mathrm{~m}$ up to the top of the section is marked by increased phyllosilicates and quartz and decreased calcite. The decrease in calcite is likely to be a function of increased dissolution, dilution by terrigenous input and consequently changes in primary productivity. As no significant dissolution has been recorded, all samples were processed for micropalaeontological analyses using standard laboratory procedures.

One hundred grams of dried sediment, for each sample were washed over a $63 \mu \mathrm{m}$ sieve and subsequently the coarse fraction was dry sieved over $125 \mu \mathrm{m}$ sieve. The fraction $>125 \mu \mathrm{m}$ was then investigated for planktonic foraminiferal content.

Planktonic foraminiferal quantitative analysis was carried out on each sample, subsampled into aliquots through a micro splitter, in order to obtain at least 300 specimens. Planktonic foraminiferal specimens were identified and counted following the taxonomic concept of Dermitzakis (1978), Kennett \& Srinivasan (1983), Iaccarino (1985), Hilgen et al. (2000) and Foresi et al. (2002). Taxon abundance is expressed as a percentage of the total planktonic fauna.

For a reliable quantitative analysis it is necessary to adopt a wide taxonomic concept, which remains 


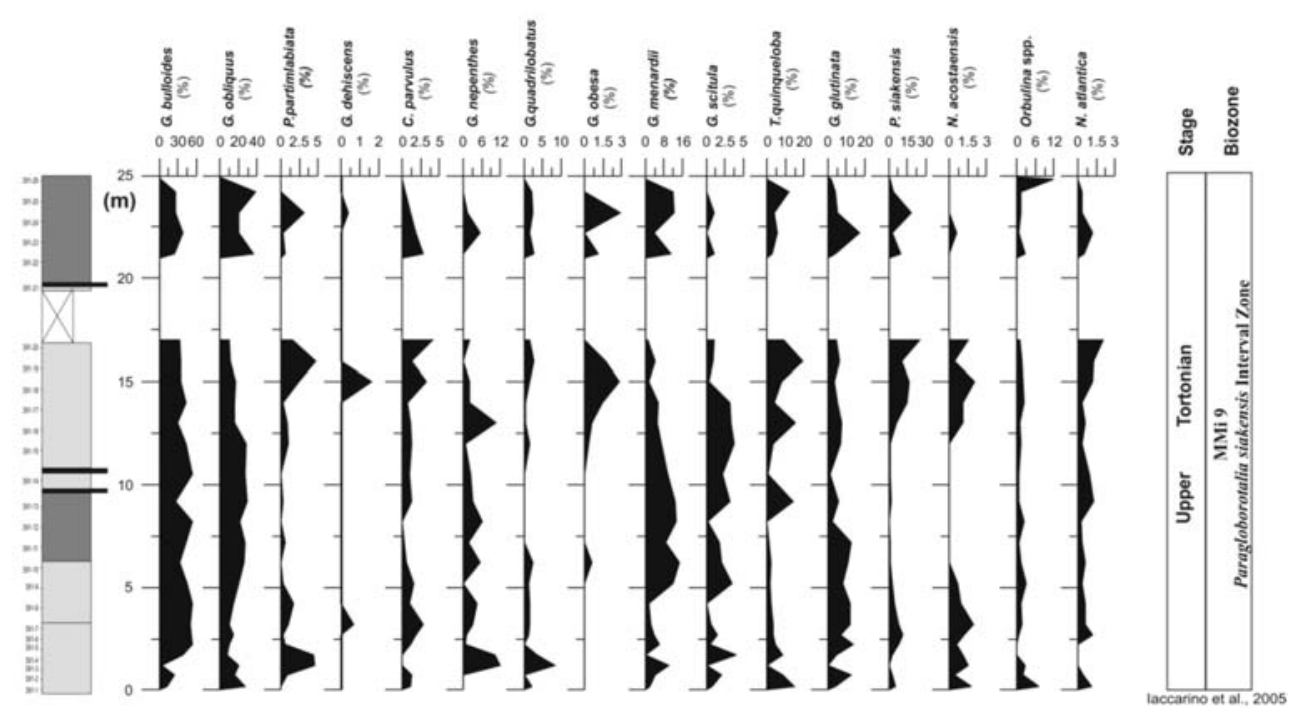

Fig. 2: Planktonic foraminifera biostratigraphy of Manassi section. Quantitative distribution of planktonic foraminifera marker species.

unchanged even under poor preservational conditions and taxonomical problems. For this reason we introduced some supra-specific categories (Foresi et al.2002), reducing the number of species which are really present in the planktonic foraminiferal data set.

Planktonic foraminiferal preservation is generally good, although at times is poor. A total of 18 taxonomic categories have been recognized: Globigerina bulloides group, Globogerinoides obliquus, Globoturborotalita apertura, Paragloborotalia cf partimlabiata, Gatapsydrax parvulus, Globoturborotalita nepenthes, Globogerinoides trilobus, Globogerina obesa, Globogerinella. siphonifera, Globorotalia. menardii group, Globorotalia scitula group, Globoquadrina dehiscens, Turborotaliata quinqueloba, Globigerinita glutinata, Paragloborotalia siakensis, Orbulina spp., Neogloboquadrina. atlantica preatlantica and Neogloboquadrina acostaensis.

The label G. bulloides group includes small-sized and poorly preserved specimens which cannot be assigned to either $G$. bulloides or G. falconensis. All tightly coiled globoturborotaliids showing a small arched aperture with lip were grouped under the label of $G$. nepenthes. Keeled globorotaliids are also counted under the label of G. menardii group. The G. scitula group is the label used for all the unkeeled globorotaliids except the $P$. cf partimlabiata. The latter species is planoconvex and has typical 4-5 chambers, an arched aperture and a relatively coarsely perforated wall structure (Hilgen et al., 2003). Relative abundance fluctuations of the most important taxonomic units are plotted in Figure 2.

The palaeoclimatic curve inferred from planktonic foraminifera assemblages was obtained by the formula $(\mathrm{w}-\mathrm{c}) /(\mathrm{w}+\mathrm{c}) \times 100$ of Amore et al. (2004), where $w$ represents the warm-water indicators and $c$ the cold water indicators. G. obliquus, G. apertura, G. dehiscens, G. trilobus, G. siphonifera, G. obesa, G. menardii group, P. siakensis and Orbulina spp. were considered warm water species, while G. scitula, G. nepenthes, T. quinqueloba, N. atlantica preatlantica, N. acostaensis and G. glutinata were considered cold water indicators (Hemleben et al., 1989; Rohling et al., 1993; Pujol \& Vergnaud-Grazzini, 1995). 


\subsection{Statistical Analysis}

The results of quantitative analysis were processed using a statistical program (SPSS13.0) in order to perform Principal Component Analysis (PCA). The analysis has been carried out in order to extract the most important factor which determines the overall faunal change. The initial dataset was condensed, and only taxa with percentages larger than $2 \%$ were considered for the analysis.

\section{Biostratigraphic results}

\subsection{Faunal changes}

Among the taxa more or less continuously present, G. bulloides gr., G. scitula gr., G. obliquus/apertura and G. glutinata show an overall upward decrease, whereas, G. quadrilobatus and Orbulina spp. show an overall upward increase. Among the species having discontinuous distribution, G. nepenthes occurs mainly in the lower part and reaches significant abundance near the base. G. obesa reaches significant percentages in the middle-upper part, whereas T. quinqueloba occurs in high abundance in the middle part. G. menardii gr. shows two main intervals of significant occurrence: in the lower and upper part of the section. C. parvulus and $P$. cf. partimlabiata are also present in our data set, but in small percentages.

Main changes in the faunal pattern are determined by the distribution of taxa having biostratigraphic significance. Within the studied interval we recorded the absence of G. subquadratus. On the contrary, G. obliquus exists in all the samples. P. siakensis also occurs in the majority of the samples, exhibiting high percentages in the middle-upper part of the section. $N$. atlantica praeatlantica is present from the base of the section and increases upward, although in small percentages. $N$. acostaensis displays a significant distributional pattern with random coiling specimens. This taxa is discontinuously present in our record in relatively small percentages (2-3\%), showing a paracme interval in its distributional range in the Mediterranean recorded at 11.54 to $11.2 \mathrm{Ma}$ (Foresi et al., 2002).

The first principal component analysis (PCA-1) describes the 21,2\% of the total variance (Fig. 3). Species yielding high negative loadings such as Orbulina sp., G. quadrilobatus and G. siphonifera are surface species indicative of warm oligotrophic conditions. Species with high positive loadings are G. bulloides which is a cold intermediate upwelling species and G. obliquus which is a warm subtropical species. The increase in abundance of the last species has been used in the middle Miocene records in Mediterranean and N. Atlantic to interpret the influence of Mi5 global cooling event in the Mediterranean record. Actually, the increase of this species at 11.54 Ma reflects the replacement of a dominant tropical fauna by a subtropical one (Zachariasse \& Spaak, 1983; Turco et al., 2001).

\subsection{Biostratigraphy}

The planktonic foraminifera biostratigraphic study of the Manassi section has been previously referred in Drinia et al. (2007). The aim of the present study is to refine and where necessary to modify the existing planktonic foraminiferal biostratigraphy of the Manassi section, by presenting the detailed distribution pattern of the marker species and all the species involved and furthermore to compare the biostratigraphic results with those have been revealed for the time equivalent astronomically tuned Mediterranean section Monte Gibliscemi (Hilgen et al., 2000). The correlation is based on the distribution pattern of selected planktonic foraminifera species (Paragloborotalia siakensis, Neogloboquadrina acostaensis, Globigerinoides obliquus).

The taxonomy and the distribution pattern of the main biostratigraphic marker species are discussed 
in more detail in the following paragraphs.

\section{Globoturborotalita apertura (Cushman), 1818 / Globigerinoides obliquus Bolli, 1957, group}

In this study G.apertura and G. obliquus were lumped into the same group in order to make our data comparable to with that observed in Monte Gibliscemi and other Mediterranean sections. This group is continuously present showing a common and regular distribution from the base up to the top of the section. The significant absence of G. subquadratus and the regular occurrence of G. obliquus is considered to be a very useful event, suggesting that the section starts after the FRO of G. obliquus, which have been recorded in Monte Gibliscemi and Tremiti Island at 11.54 (Hilgen et al., 2000; Foresi et al. 2002).

The LCO of G. subquadratus followed by the FCO of G. obliquus are near synchronous in Mediterranean calibrated at $11.54 \mathrm{Ma}$ (Hilgen et al., 2000). This succession is also recorded at Site 926 (equatorial Atlantic, Turco et al., 2002), although the FRO of G. obliquus (11.17 Ma) there, is about 400kyr younger than LO of G. subquadratus. In addition, both at site 926 and the Mediterranean the LCO of G. subquadratus is slightly preceded the by the LCO of D. kugleri.

\section{Paragloborotalia siakensis (Le Roy), 1939}

Although this species is abundant and continuously present shows a decline in its distributional pattern from 6 to $12 \mathrm{~m}$. P. siakensis is a long ranging species displaying several distributional changes of biostratigraphic significance. According the Hilgen et al. (2000) and Foresi et al. (2002), the LO occurrence of this species has being dated at 11.2 Ma.

Neogloboquadrina Bandy, Frerichs and Vincent, 1967: N. acostaensis (Blow), 1959, N. atlantica praeatlantica (Berggren), 1972

The neogloboquadrinids are represented by $N$. atlantica praeatlantica (small-sized N. atlantica of Hilgen et al., 2000; Hilgen et al., 2003) and N. acostaensis. These two species are separately plotted, although their distributional pattern seems to be the same being rare and discontinuously present in the section ranging between $2-5 \%$ of the total data set, with random coiling specimens. The arrival of neogloboquadrinids into the Mediterranean has been dated at $11.78 \mathrm{Ma}$ (Hilgen et al., 2000). A paracme interval of this group has been recorded in several Mediterranean sections dated at 11.54-11.21 (Hilgen et al, 2000; Turco et al., 2001; Foresi et al., 2002; Hilgen et al., 2003); In Monte Gibliscemi rare and scattered occurrences have been recorded between 11.54 and $11.17 \mathrm{Ma}$, whereas this group become the major faunal constituent up to that point. The base of the paracme interval coincides with the LCO of G. subquadratus and the FRO of G. obliquus, whereas the end of this interval postdates the LO of P. siakensis.

\section{Catapsydrax parvulus Bolli, Loeblich and Tappan, 1957}

The species is almost continuously present in small number showing similar distribution with the Tremiti section (Foresi et al., 2002).

\section{Paragloborotalia partimlabiata (Ruggieri and Sprovieri), 1970}

This species is present in the section in low percentages. Peaks in abundance of this species coincide with low occurrence of $P$. siakensis.

The comparison with astronomically calibrated sequences allowed us to consider as starting point 


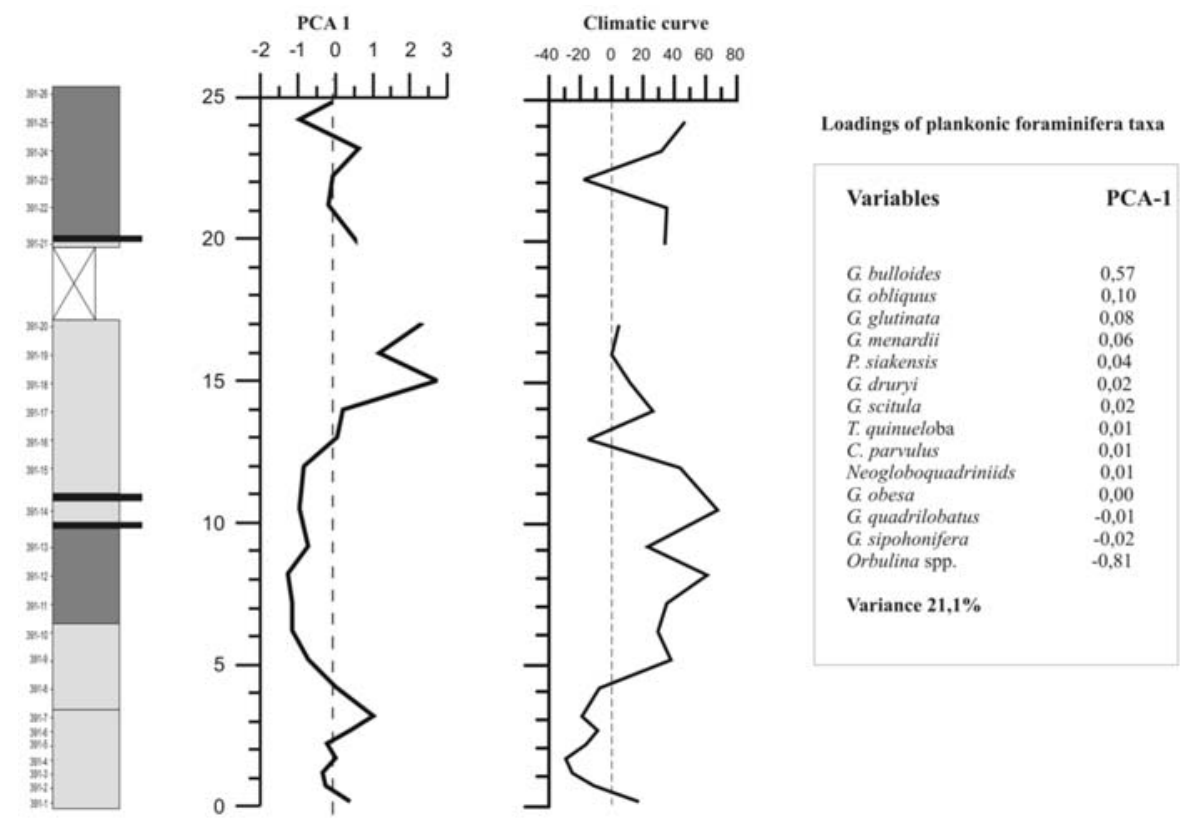

Fig. 3: PCA-1 scores plotted and palaeoclimatic curve.

of our tuning, the regular occurrence of Globigerinoides obliquus, and the total absence of Globigerinoides subquadratus. The LCO of the last species is dated at $10.539 \mathrm{Ma}$ in Monte Gibliscemi, whereas the FRO of G. obliquus is recorded at the same time. The paracme interval of N.acostaensis and N.atlantica recorded at Monte Gibliscemi as well as in Monte dei Corvi (Hilgen et al., 2003) and in Tremiti Island (Foresi et al, 2002) dated at 11.55-11.21 Ma. These biochronological datums together with the distribution pattern of $P$. siakensis yielded ages for the studied section between 11.54 to $11.2 \mathrm{Ma}$, determining the Paragloborotalia siakensis planktonic foraminifera Interval Zone of Iaccarino et al., 2005, for Manassi section.

\section{Palaeoenvironmental-palaeoclimatic implications}

A surface-water temperature approach in this study has been based on planktonic foraminifera ecological preference. On the basis of the obtained palaeoclimatic curve (Fig. 3) and the planktonic foraminifera abundance fluctuations, we could recognise the following climatic intervals during the deposition of the Manassi section.

The first interval extends from 0.75 to $4.2 \mathrm{~m}$, showing higher percentages of cold-water planktonic foraminifera and negative values of the palaeoclimatic curve. In this interval, T. quinqueloba and $G$. glutinata are generally abundant occurring in high percentages, whereas $G$. scitula shows low frequency values. More precisely, at $1.2 \mathrm{~m}, G$. nepenthes, a cold intermediate species, first appears with maximum frequency value about $50 \%$ and then strongly declines to very low values. In parallel, the warm-water species occur in low percentages. Therefore, we interpret this interval as a period characterised by generally cool conditions.

On the other hand, from 5.2 to $12 \mathrm{~m}$, a warming phase is distinctively recorded. This climatic improvement is recorded by the increase of the warm-water species G. obliquus and G. menardii gr. 
and the decrease of T. quinqueloba and N. acostaensis and N. atlantica. The planktonic foraminiferal assemblage is dominated by the tropical-subtropical surface dwellers G. obliquus/apertura and the tropical intermediate species G. menardii.

The above mentioned warming interval continues up to $24.2 \mathrm{~m}$, punctuated by several negative peaks in the palaeoclimatic curve. The overall warming trend is reflected by the relative high abundance of P. siakensis, Orbulina spp., G. obliquus and G. apertura. Negative values are recorded by the temporary decrease of warm water taxa and increase of cool fauna.

The long-term trend in PCA-1 reveals that the faunal composition of the studied interval changed significantly at 4.2 and $12 \mathrm{~m}$ of the section. The first distinct shift to positive loadings at the base of the section actually reflects the relative high abundances of $N$. atlantica, G. scitula T. quinqueloba and $G$. nepenthes, an association of cool water indicators.

The shift towards negative values at $4.2 \mathrm{~m}$ marks a significant reduction of neogloboquadriniids and a coincidently increase of the tropical species $G$. menardii. This observation fits well with the warming phase which is observed in the palaeoclimatic curve.

The positive shift recorded at $15 \mathrm{~m}$ and $23 \mathrm{~m}$ in the PCA-1 is not well understood as this is in contrast with the palaeoclimatic curve. Both intervals are characterized by an increase in P. siakensis and $N$. atlantica. This opposite configuration in the PCA-1 is probably reflecting changes in nutrient supply rather than climatic fluctuations. As it has been previously reported P. siakensis is not a typical oligotrophic taxon, as it is related with sediments where eutrophic conditions prevail (Lirer et al., 2004).

\section{Discussion}

In order to attempt a palaeoclimatic reconstruction of early late Miocene in Ionian Sea area, evidence from the Atlantic and other Mediterranean sections are compared based on ecologic biostratigraphic and climatic data derived from planktonic foraminifera. The early late Miocene open ocean isotope record is characterized by an increased value known as Mi5 event (Miller et al., 1991). Mi5 event is positioned at the base of chron C5r by Miller et al. (1991) at about 11.7 Ma and biostratigraphically within the range of $D$. kugleri (Turco et al., 2001) between 11.868 and $11.573 \mathrm{Ma}$ (ages after Turco et al., 2002). It is worth mentioning that at Site 1085, the D. kugleri zone is located between 11.9 and $11.5 \mathrm{Ma}$, indicating that this increase corresponds to the Mi5 event. Recent results from an astronomically dated deep marine succession in the Mediterranean (Gibliscemi section) indicate that the Mi5 event occurred at 11.4 (Turco et al., 2001), representing a deep water cooling. The onset of this event has been micropaleontologically correlated with the invasion of the neogloboquadriniids (N. atlantica and N. acostastaensis) into the Mediterranean, as well as the successive entries of the cool subtropical species G. falconensis and Globoquadrina sp. According the same authors the earliest neogloboboquadriniids vanished from Mediterranean at 11.55 Ma predating the maxima of $\delta^{18} \mathrm{O}$. The upper part of Mi5 event is marked by the near absence of neogloboquadriniids and the replacement of a tropical fauna association by a subtropical one.

Our data support these assumptions and point to a pronounced global climatic cooling affected the Ionian basin. The cooling event is followed by a warming phase characterized by an increase in the tropical G. menardii and the tropical-subtropical G. obliquus species, whereas P. siakensis, a general warm but not typical oligotrophic species exists in its minimum abundance. The further reduction of the neogloboquadriniids during this interval suggests oligotrophic and warm conditions prevail probably due to intensification of monsoons. More explicitly, the intensification of monsoons is related to eccentricity maxima (precession minima), when high amplitude oscillations oc- 
curs in summer insolation. During precession minima, high temperature and oligotrophic conditions are evident by high abundances of G. obliquus and G.quadrilibatus. The intensification of monsoon is possible accompanied by intensive run off and low salinities in surface water column, as evidenced by an increase of $P$. siakensis, reflecting a period of eutrophic conditions.

\section{Conclusions}

Plankton biostratigraphy in this study confirms the interval between 11.54 Ma to 11.2 Ma for the deposition of the sediments of Manassi section by the regular occurrence of G. obliquus the absence of $G$. subquadratus, the near absence of neogloboquadriniids and the distribution pattern of $P$. siakensis. The surface-water temperature approach based on planktonic foraminifera ecological preferences allowed the recognition of five palaeoclimatic events superimposed on the long-term climatic trend supported by the principal component analysis applied on the total data set. The faunal composition suggests a cooling trend in the lower part, which has been correlated with the Mi5 event. This cooling event is followed by a warm-temperate phase, punctuated by several negative peaks in the palaeoclimatic curve. This interval has been attributed to the intensification of monsoon activity with an increase of run off that occurred at times of precession minima.

The palaeoclimatic evolution of the study area generally corresponds to the global palaeoclimatic trend with some subtle differences, supporting that the regional climate of this area was not merely controlled by global changes in climate. Further studies based on other palaeoclimatic proxies (e.g. $\delta^{18} \mathrm{O}$ ) are needed in order to establish the palaeoclimatic reconstruction of the studied area.

\section{Acknowledgements}

Funding has been provided partly by Research Project 70/4/8642 financed by National Kapodistrian University of Athens and the Greek-Italian Joint Research Project. The author would like to thank Dr. N. Tsaparas for help during field work and Assist. Prof. H. Drinia for discussion and comments.

\section{References}

Amore, F.O., Caffau, M., Massa, B., Morabito, S., 2004. Late Pleistocene-Holocene paleoclimate and related paleoenvironmental changes as recorded by calcareous nannofossils and planktonic foraminifera assemblages in the southern Tyrrhenian Sea (Cape Palinuro, Italy). Marine Micropaleontology 52 (1-4), 255-276.

Aubouin, J., 1965. Geosynclines. Developments in Geotectonics; 1. Elsevier, Amsterdam.

Bornovas, J., 1964. Géologie de l' île de Lefkade. Geological. \& Geophysics Research (I.G.S.R.), 10, $142 \mathrm{pp}$.

De Mulder, E.F.J., 1975. Microfauna and sedimentary-tectonic history of the Oligo-Miocene of the Ionian Islands and Western Epirus (Greece). Utrecht Micropaleontol. Bul.l 13, 1-139.

Dermitzakis, M. D., 1978. Stratigraphy and sedimentary history of the Miocene of Zakynthos (Ionian Islands, Greece). Annales Geologique des Pays Helleniques, 29, 47-186.

Drinia, H., Antonarakou, A., Kontakiotis, G., Tsaparas, N., Segou, M. \& Karakitsios, V., 2007. Paleobathymetric Evolution of the Early Late Miocene Deposits of the Pre-Apulian Zone, Levkas Island, Ionian Sea. Bulletin Geological Society of Greece, 40/1, 39-52.

Flower, B.P. and Kennett, J.P., 1993. Middle Miocene ocean-climate transition: high resolution oxygen and carbon isotopic records from DSDP Site 588A southern Pacific. Paleoceanography, 8, 811-843. 
Flower, B.P. and Kennett, J.P., 1995. Middle Miocene deep water paleoceanography in the southwest Pacific: Relations with East Antarctic ice sheet development. Paleoceanography, 10, 1095-1112.

Foresi, L.M., Bonomo, S., Caruso, A., Di Stefano, A., Di Stefano, E., Iaccarino, S. M., Lirer, F., Salvatorini, G. \& Sprovieri, R., 2002. High resolution calcareous plankton biostratigraphy of the Serravalian succession of the Tremiti Islands (Adriatic Sea, Italy). In Iaccarino, S.M. (ed.), Intergrated Stratigraphy and Paleoceanography of the Mediterranean Middle Miocene. Rivista Italiana di Paleontologia e Stratigrafia, 108, 257-273.

Hemleben, Ch., Spindler, M. \& Anderson, O.R., 1989. Modern Planktic Foraminifera. Springer-Verslang, New-York, 363pp.

Hilgen, F.J., Abdul Aziz, H., Krijgsman W., Raffi I. \& Turco, E., 2003. - Integrated stratigraphy and astronomical calibration of the Serravallian and lower Tortonian at Monte dei Corvi (Middle-Upper Miocene, northern Italy). Palaeogeography, Palaeocimatology, Palaeoecology, 199: 229-264.

Hilgen, F.J., Krijgsman, W., Raffi, I., Turco, E. \& Zachariasse, W.J., 2000. Integrated stratigraphy and astronomical calibration of the Serravallian/Tortonian boundary Section at Monte Gibliscemi (Sicily, Italy). Marine Micropaleontology, 38, 181-211.

Holbourn, A., Kuhnt, W., Simo, J.A., Li, Q., 2004. Middle Miocene isotope stratigraphy and paleoceanographic evolution of the northwest and southwest Australian margins (Wombat Plateau and Great Australian Bight). Palaeogeography, Palaeocimatology, Palaeoecology, 208, 1 -22.

Iaccarino S., Premoli Silva I., Biolzi M., Foresi L.M., Lirer F., Petrizzo M.R., 2005. Practical manual of Oligocene to Middle Miocene Planktonic Foraminifera (Ed by Biolzi M., Iaccarino S., \& Rettori R.). International School on Planktonic Foraminifera $4^{\circ}$ Course. Perugia 14-18 February. University of Perugia Press.

Iaccarino, S., 1985. Mediterranean Miocene and Pliocene planktic Foraminifera. In Bolli H.M., Saunders J.B. \& Perch-Nielsen K. (eds.), Plankton Stratigraphy. Cambridge Univ. Press, London, 283-314.

IGRS-IFP, 1966. Etude géologique de l'Epire (Grèce nord occidentale). Editions Technip, Paris, 306pp.

Kaiho, K., 1994: Benthic foraminiferal dissolved oxygen index and dissolved oxygen levels in the modern ocean. Geology, 22: 719-722.

Keller, G. and Barron, J.A., 1987. Paleodepth distribution of Neogene deep-sea hiatuses. Paleoceanography 2, 697- 713 .

Kennett, J.P. and Srinivasan, M.S., 1983. Neogene Planktonic Foraminifera: A Phylogenetic Atlas: Stroudsburg, PA (Hutchinson Ross).

Kennett, J.P. and Barker, P.F., 1990. Latest Cretaceous to Cenozoic climate and oceanographic developments in the Weddel Sea, Antarctica: An ocean-drilling perspective. Proc. Ocean Drill. Program Sci. Results, 113, 937-960.

Lekkas, E., Danamos, G., Lozios, S., 2001. Neotectonic structure and neotectonic evolution of Lefkada island. Bull. Geol. Soc., Greece, XXXIV/1, 157-163.

Lirer, F., Caruso, A., Foresi, L.M., Iaccarino, S. \& Iacumin, P., 2004. Paleoclimatic changes in the Serravallian record of the Mediterranean area, in Coccioni R., Galeotti S. \& Lirer F., (eds), Proceedings of the first Meeting of Environmental Micropaleontology for Young Italian Researcher. Grybowski Foundation Sp. Publ., 9, 77-96. Micropaleontology, 6, 423-450.

Miller, K.G., Fairbanks, R.G. \& Mountain, G.S., 1987. Tertiary oxygen isotope synthesis, sea level history and continental margin erosion. Paleoceanography, 2, 1-19.

Miller, K.G., Feigenson, J.D., Wright, J.D. \& Clement, B.M., 1991b. Miocene isotope reference section, Deep Sea Drilling Project, Site 608: An evaluation of isotope and biostratigraphic resolution. Paleoceanography, 6, 33-52. 
Miller, K.G., Wright, J.D. \& Fairbanks, R.G., 1991. Unlocking the ice house: Oligocene-Miocene oxygen isotopes, eustasy and margin erosion. Journal of Geophysical Research, 96B, 6829-6848.

Ohta, S., Kaiho, K. \& Takei, T. 2003. Relationship between surface-water temperature and ice-sheet expansion during the Middle Miocene, Palaeogeography, Palaeoclimatology, Palaeoecology, 201(34), 307-320.

Pujol, A. And Vergnaud-Grazzini, C., 1995. Distribution patterns of live planktic foraminifera as related to regional hydrography and productive systems of the Mediterranean Sea. Marine Micropaleontology $25,187-217$.

Rohling, E.J., Jorissen, F.J., Vergnaud-Grazzini, C., \& Zachariasse, W.J., 1993. Northern Levantine and Adriatic Quaternary planktic foraminifera; Reconstruction of paleoenvironmental gradients. Marine Micropaleontology, 21, 191-218.

Savin, S.M., Douglas, R.G. \& Stehli, F.G., 1975. Tertiary marine paleotemperatures. Geological Society of America, Bulletin, 86, 1499-1520.

Savin, S.M., Douglas, R.G., Keller, G., Killingley, J.S., Shaughnessey, L., Sommer, M.A., Vincent, E., and Woodruff, F., 1981. Miocene benthic foraminiferal isotope record: A synthesis. Marine Micropaleontology, $6,423-450$.

Schakleton, N.J. and Kennett, J.P., 1975. Late Cenozoic oxygen and carbon isotope changes at DSDP site 284: Implications for glacial history of the northern hemisphere and Antarctica. Init. Rep. Deep Sea Drill.Proj., 29, 801-807.

Turco, E., Bambini, A.M., Foresi, L.M., Iaccarini, S., Lirer, F., Mazzei, R., Salvatorini, G., 2002. Middle Miocene high-resolution calcareous plankton biostratigrphy at Site (Leg 154, equatorial Atlantc Ocean): paleoecological implications. Geobios, special volume 24, 257-276.

Turco, E., Hilgen, F.J., Lourens, L.J., Shackleton, N.J. \& Zachariasse, W.J., 2001. Punctuated evolution of global climate cooling during the late Middle to early Late Miocene: High-resolution planktonic foraminiferal and oxygen isotope records from the Mediterranean. Paleoceanography, 16, 405-423.

Underhill, J.R., 1989. Late Cenozoic deformation of the Hellenic foreland, Western Greece. Bulletin of the Geological Society of America, 101, 613-634.

Woodruff, F., Savin, S. \& Douglas, R.G., 1981. Miocene stable isotope record: a detailed deep Pacific Ocean study and its paleoclimatic implications. Science, 212, 665-668.

Woodruff, F. and Savin, S.M. 1991. Mid-Miocene isotope stratigraphy in the deep sea: high-resolution correlations, paleoclimatic cycles, and sediment preservation. Paleoceanography, 6, 755-806.

Zachariasse, W.J. and Spaak, P., 1983. Middle Miocene to Pliocene paleoenvironmental reconstruction of the Mediterranean and adjacent Atlantic Ocean: planktonic foraminiferal record of southern Italy, in: Reconstruction of Marine Paleoenvironments, J.E. Meulenkamp, ed. Utrecht Micropaleontol. Bull., 30, 91-110.

Zachos, J., M. Pagani, L. Sloan, E. Thomas, \& Billups, K., 2001. Trends, rhythms, and aberrations in global climate 65 Ma to Present. Science, 292, 686-693. 